University of New Hampshire

University of New Hampshire Scholars' Repository

7-15-1994

\title{
Soluble acidic species in air and snow at Summit, Greenland
}

Jack E. Dibb

University of New Hampshire, jack.dibb@unh.edu

R. Talbot

University of New Hampshire, robert.talbot@unh.edu

$\mathrm{M} \mathrm{H}$. Bergin

Carnegie Mellon University

Follow this and additional works at: https://scholars.unh.edu/earthsci_facpub

Part of the Atmospheric Sciences Commons

\section{Recommended Citation}

J. E. Dibb, R. W. Talbot, and M. H. Bergin, "Soluble acidic species in air and snow at summit, Greenland," Geophysical Research Letters, vol. 21, no. 15, pp. 1627-1630, Jul. 1994.

This Article is brought to you for free and open access by the Earth Sciences at University of New Hampshire Scholars' Repository. It has been accepted for inclusion in Earth Sciences Scholarship by an authorized administrator of University of New Hampshire Scholars' Repository. For more information, please contact Scholarly.Communication@unh.edu. 


\title{
Soluble acidic species in air and snow at Summit, Greenland
}

\author{
Jack E. Dibb, ${ }^{1}$ Robert W. Talbot, ${ }^{1}$ and Michael H. Bergin ${ }^{2}$
}

\begin{abstract}
Simultaneous measurements of the concentrations of soluble acidic species in the gas, aerosol and snow phases at Summit, Greenland were made during summer 1993. Mean concentrations of gas phase $\mathrm{HCOOH}, \mathrm{CH}_{3} \mathrm{COOH}$, and $\mathrm{HNO}_{3}\left(49 \pm 28,32 \pm 17\right.$ and $0.9 \pm 0.6 \mathrm{nmol} \mathrm{m}^{-3} \mathrm{STP}$, respectively) exceeded the concentrations of aerosol-associated $\mathrm{HCOO}^{-}, \mathrm{CH}_{3} \mathrm{COO}^{-}$, and $\mathrm{NO}_{3}^{-}$by 1-3 orders of magnitude. On average, $\mathrm{SO}_{2}$ concentrations $\left(0.9 \pm 0.6 \mathrm{nmol} \mathrm{m} \mathrm{m}^{-3} \mathrm{STP}\right)$ were approximately $1 / 3$ those of aerosol $\mathrm{SO}_{4}{ }^{2}$, but this ratio varied widely due largely to changes in the concentration of aerosol $\mathrm{SO}_{4}=$. Concentrations of aerosol $\mathrm{SO}_{4}=$ plus $\mathrm{SO}_{2}$ consistently exceeded the sum of aerosol $\mathrm{NO}_{3}^{-}$plus $\mathrm{HNO}_{3}$, yet $\mathrm{NO}_{3}^{-}$was 3-20 times as abundant as $\mathrm{SO}_{4}{ }^{-}$in surface snow. Gas phase concentrations of $\mathrm{HCOOH}$ and $\mathrm{CH}_{3} \mathrm{COOH}$ at Summit were unexpectedly as large as those previously reported for several high latitude continental sites. However, carboxylate concentrations in snow were lower than those of $\mathrm{SO}_{4}=$. Our observation of post-depositional loss of these carboxylic acids within hours after a snowfall must partially explain the low concentrations found in snow. The relative abundance of soluble acids in summer snow at Summit was opposite of that in the overlying atmosphere. Our results highlight the need for improved understanding of the processes controlling transfer of soluble atmospheric species between air and snow.
\end{abstract}

\section{Introduction}

Deposition of aerosol $\mathrm{NO}_{3}^{-}$(hereafter $\mathrm{p}-\mathrm{NO}_{3}{ }^{-}$) and gaseous $\mathrm{HNO}_{3}$ is the major atmospheric sink for total reactive nitrogen $\left(\mathrm{NO}_{\mathrm{y}}\right.$ ) [e.g., Logan, 1983]. Since $\mathrm{NO}_{\mathrm{y}}$ is involved in many important atmospheric photochemical reactions [e.g., Logan, 1983], Greenland ice core records of nitrate (p- $\mathrm{NO}_{3}^{-}$plus $\mathrm{HNO}_{3}$ ) accumulation could provide insight into past photochemical and oxidative states of the troposphere. However, it is not clear that the relationship between $\mathrm{NO}_{3}^{-}$ concentration in snow and that of $\mathrm{NO}_{y}$ in the overlying atmosphere is straightforward, nor is it certain that ice cores preserve a simple record of the deposition of total tropospheric nitrate at the site [Wolff, 1993].

In this paper we report measurements of $\mathrm{HNO}_{3}, \mathrm{p}-\mathrm{NO}_{3}{ }^{-}$ and snow $\mathrm{NO}_{3}^{-}$made at Summit in summer 1993. Parallel results for $\mathrm{HCOOH}, \mathrm{CH}_{3} \mathrm{COOH}, \mathrm{SO}_{2}$ and $\mathrm{SO}_{4}{ }^{=}$in the three phases are also presented. We examine differences in air/ snow transfer functions for these species in relation to their gas-aerosol partitioning and their behavior during snow and fog events. Early (hours to days) post-depositional changes in snow chemistry after such events are also discussed.

\footnotetext{
${ }^{1}$ Institute for the Study of Earth, Oceans and Space, University of New Hampshire

${ }^{2}$ Department of Civil Engineering, Carnegie Mellon University
}

Copyright 1994 by the American Geophysical Union.

Paper number 94GL01031

0094-8534/94/94GL-01031\$03.00

\section{Methods}

Gas phase concentrations of the soluble acids were determined by mist chamber sampling techniques, wherein the gases are concentrated into a small volume of ultrapure water. This technique quantitatively collects $\mathrm{HNO}_{3}$, and the collection efficiencies for the other acids of interest exceed 95\% [Keene et al., 1988; Talbot et al., 1990a; Klemm and Talbot, 1991]. The stripping solutions were all analyzed by ion chromatography, in the field for $\mathrm{NO}_{3}^{-}$and some of the blanks, and back in New Hampshire for $\mathrm{SO}_{2}$ and the carboxylates. The samples returned for analysis were frozen to $-20^{\circ} \mathrm{C}$ within 30 minutes of collection and maintained frozen until just before analysis.

Four 3-hour samples day-1 (volumes of 1.6-1.8 $\mathrm{m}^{3} \mathrm{STP}$ ) were collected (starting at 05:00, 11:00, 17:00 and 23:00 local time) for at least 3 consecutive days. A total of 36 samples were collected 20-22 June, 5-8 July and 18-20 July. No sampling was conducted until several blanks with acceptably low concentrations of $\mathrm{NO}_{3}^{-}$were obtained before each sampling period. Uncertainties for $\mathrm{HNO}_{3}, \mathrm{SO}_{2}$, $\mathrm{HCOOH}$ and $\mathrm{CH}_{3} \mathrm{COOH}$ concentrations were approximately $0.1,0.3,1.2$ and $1.2 \mathrm{nmol} \mathrm{m}^{-3} \mathrm{STP}$, respectively.

During gas phase sampling, five replicate surface snow samples were collected at the mid-time of each mist chamber sample. A full suite of soluble organic and inorganic ions were measured in these samples by ion chromatography. Large volume aerosol samples were also collected through the first two intervals, on 8:00-20:00/20:00-8:00 and 8:00-24:00 schedules for the determination of natural radionuclides and soluble ionic species, respectively [Dibb et al., 1992].

\section{Results}

\section{Overview}

Gas phase concentrations over Summit, Greenland are compared to those from previous studies in northern high latitudes in Table 1. The mean aerosol composition reported for Summit represents only 10 samples, 5 each from late June and early July. Reported values for $\mathrm{p}-\mathrm{NO}_{3}{ }^{-}$and $\mathrm{p}-\mathrm{SO}_{4}=$ were lower than the seasonal averages $\left(0.4\right.$ and $4.2 \mathrm{nmol} \mathrm{m}^{-3}$ STP, respectively), while the opposite was true for p-HCOOand $\mathrm{p}-\mathrm{CH}_{3} \mathrm{COO}^{-}$(season means 0.3 and $0.06 \mathrm{nmol} \mathrm{m}^{-3} \mathrm{STP}$, respectively). It is unclear whether the reported mean gas phase concentrations are similarly biased.

Nitric acid concentrations were more than an order of magnitude higher than those of $\mathrm{p}-\mathrm{NO}_{3}^{-}$(Table 1), in accord with the denuder results of Silvente [1993]. However, the mean concentrations in 1993 were $>3$ times the background levels reported for 1991 [Silvente, 1993]. On the other hand, $\mathrm{HNO}_{3}$ concentrations at Summit were $\leq 1 / 2$ the free tropospheric (1-6 km) mean during ABLE 3A and about $1 / 2$ the mean for "background" air during ABLE 3B (Table 1). Concentrations of $\mathrm{p}-\mathrm{NO}_{3}^{-}$at Summit were lower than any previously reported for the region (Table 1). 
Table 1. Summary couparison of gaseous and aerosol acid concentrations ( $\mathrm{nmol} \mathrm{m}^{-3} \mathrm{STP}$ ) at Summit and other high northern latitude regions.

\begin{tabular}{|c|c|c|c|c|c|c|c|c|c|c|}
\hline & & $\mathrm{HNO}_{3}$ & $\mathrm{p}-\mathrm{NO}_{3}$ & $\mathrm{SO}_{2}$ & $\mathrm{p}-\mathrm{SO}_{4}=$ & HCOOH & p.HCOO- & $\mathrm{CH}_{3} \mathrm{COOH}$ & $\mathrm{p}-\mathrm{CH}_{3} \mathrm{COO}^{-}$ & source \\
\hline $\begin{array}{l}\text { Summit, Greenlat } \\
\text { Summer } 1993 \\
72^{\circ} 25^{\prime} \mathrm{N} \\
36^{\circ} 40^{\prime} \mathrm{W}\end{array}$ & $\begin{array}{l}\text { Ind: } \\
\text { mean } \pm \sigma \\
\text { median } \\
\text { range }\end{array}$ & $\begin{array}{l}0.9 \pm 0.6 \\
0.9 \\
0.19-2.44\end{array}$ & $\begin{array}{l}0.06 \pm 0.06 \\
0.03 \\
\text { n.d. }-0.15\end{array}$ & $\begin{array}{l}0.9 \pm 0.6 \\
0.8 \\
0.15-3.63\end{array}$ & $\begin{array}{l}3.0 \pm 2.3 \\
2.4 \\
30.6-7.1\end{array}$ & $\begin{array}{l}49 \pm 28 \\
45 \\
8.6-119.2\end{array}$ & $\begin{array}{l}1.05 \pm 2.31 \\
0.15 \\
2 \text { n.d. }-7.53\end{array}$ & $\begin{array}{l}32 \pm 17 \\
34 \\
6.6-72.5\end{array}$ & $\begin{array}{l}0.16 \pm 0.33^{T} \\
0.04 \\
\text { n.d. }-1.07\end{array}$ & This Work \\
\hline $\begin{array}{l}\text { ABLE 3A Airbor } \\
\text { Summer } 1988 \\
\text { High Arctic } \\
\text { Sub-Arctic }\end{array}$ & $\begin{array}{l}\text { ne Campaig } \\
\text { mean } \pm \sigma \\
\text { mean } \pm \sigma\end{array}$ & $\begin{array}{l}2.0 \pm 1.1 \\
2.6 \pm 1.4\end{array}$ & $\begin{array}{l}0.98 \pm 0.53 \\
0.67 \pm 0.31\end{array}$ & & $\begin{array}{l}5.7 \pm 3.4 \\
1.8 \pm 10\end{array}$ & $\begin{array}{l}7.3 \pm 4.7 \\
8.5 \pm 3.2\end{array}$ & $<0.2$ & $\begin{array}{r}9.2 \pm 4.6 \\
10.0 \pm 3.1\end{array}$ & $\begin{array}{l}<0.4 \\
<0.4\end{array}$ & Talbot et al, 1992 \\
\hline $\begin{array}{l}\text { ABLE 3B Airbor } \\
\text { Summer } 1990 \\
\text { "Background" Air } \\
\text { Burning Plumes }\end{array}$ & $\begin{array}{l}\text { ne Campalg } \\
\text { mean } \pm \sigma \\
\text { mean } \pm \sigma\end{array}$ & $\begin{array}{l}1.7 \pm 0.1 \\
26.0 \pm 5.0\end{array}$ & $\begin{array}{l}0.2 \pm 0.1 \\
18 \pm 2.6\end{array}$ & & $\begin{array}{r}3.7 \pm 4.4 \\
10.0 \pm 7.0\end{array}$ & $\begin{array}{r}20 \pm 1 \\
100 \pm 5\end{array}$ & $<0.2$ & $\begin{array}{l}25 \pm 1 \\
86 \pm 4\end{array}$ & $\begin{array}{l}<0.4 \\
<0.4\end{array}$ & $\begin{array}{l}\text { Lefer et al, } 1994 \\
\text { Gorzeiska ef al., } 1994 \\
\text { Talbot et al }, 1994\end{array}$ \\
\hline $\begin{array}{l}\text { ABLE 3B Scheffe } \\
\text { Summer } 1990 \\
54^{\circ} 52^{\prime} \mathrm{N} \\
66^{\circ} 39^{\prime} \mathrm{W}\end{array}$ & $\begin{array}{c}\text { erville Towe } \\
\text { mean } \pm \sigma \\
\text { median } \\
\text { range }\end{array}$ & $\begin{array}{l}\text { Site: } \\
4.2 \pm 4.0 \\
2.7 \\
0.6-19.4\end{array}$ & $\begin{array}{l}3.1 \pm 2.9 \\
3.1 \\
\text { n.d. } \cdot 8.2\end{array}$ & $\begin{array}{l}2.1 \pm 2.2 \\
1.2 \\
\text { n.d. }-12.0\end{array}$ & $\begin{array}{l}8.1 \pm 6.7 \\
5.2 \\
2.9-23.9\end{array}$ & $\begin{array}{l}49 \pm 31 \\
45 \\
8.1 \cdot 222.0\end{array}$ & $\begin{array}{l}<0.4 \\
0\end{array}$ & $\begin{array}{l}42 \pm 24 \\
38 \\
10.8-166.4\end{array}$ & $\begin{array}{l}<0.9 \\
4\end{array}$ & $\begin{array}{l}\text { Klemm et al, } 1994 \\
\text { phus unpublished } \\
\text { aerosol dasa }\end{array}$ \\
\hline $\begin{array}{l}\text { Alert, Canada: } \\
\text { Winter - Spring } 1 \\
82^{\circ} 30^{\circ} \mathrm{N} \\
62^{\circ} 18 \mathrm{~W}\end{array}$ & $\begin{array}{c}1988 \\
\text { mean } \pm \sigma \\
\text { median } \\
\text { range }\end{array}$ & $\begin{array}{l}1.3 \pm 0.9 \\
1.0 \\
0.04-2.9\end{array}$ & $\begin{array}{l}1.4 \pm 1.0 \\
1.2 \\
0.1 \cdot 4.2\end{array}$ & $\begin{array}{c}20.0 \pm 19.7 \\
13.3 \\
0.5-86.9\end{array}$ & $\begin{array}{l}24.8 \pm 15.8 \\
18.6 \\
4.9 \cdot 65.4\end{array}$ & & & & & Bollenherm et al , 1993 \\
\hline $\begin{array}{l}\text { Barrow, A laska: } \\
\text { Winter-Spring } 1 \\
71^{\circ} 19 \mathrm{~N} \\
156^{\circ} 37 \mathrm{~W}\end{array}$ & $\begin{array}{l}1986 \\
\text { mean } \pm \sigma \\
\text { median }\end{array}$ & & $\begin{array}{l}2.0 \pm 0.2 \\
1.4\end{array}$ & & $\begin{array}{c}10.8 \pm 1.5 \\
4.3\end{array}$ & & $\begin{array}{l}5.3 \pm 0.7 \\
2.9\end{array}$ & & $\underset{5.4}{124 \pm 2.2}$ & Li and Winchesier, 1989a,b \\
\hline
\end{tabular}

Overall, ${\mathrm{p}-\mathrm{SO}_{4}}^{=}$was about 3 times as abundant as $\mathrm{SO}_{2}$ at Summit (Table 1; Fig. 1). The seasonal mean concentration of $\mathrm{p}^{-\mathrm{SO}_{4}}{ }^{-}$at Summit was bracketed by previously reported values for the high-latitude summer troposphere (Table 1). Wintertime observations at Alert and Barrow are characterized by much higher concentrations of $\mathrm{SO}_{2}$ and $\mathrm{p}-\mathrm{SO}_{4}{ }^{=}$, as well as higher values of the ratio $\mathrm{SO}_{2} / \mathrm{SO}_{4}{ }$, reflecting the influence of Arctic haze [e.g., Barrie and Bottenheim, 1991].

Both carboxylic acids were nearly entirely in the gas

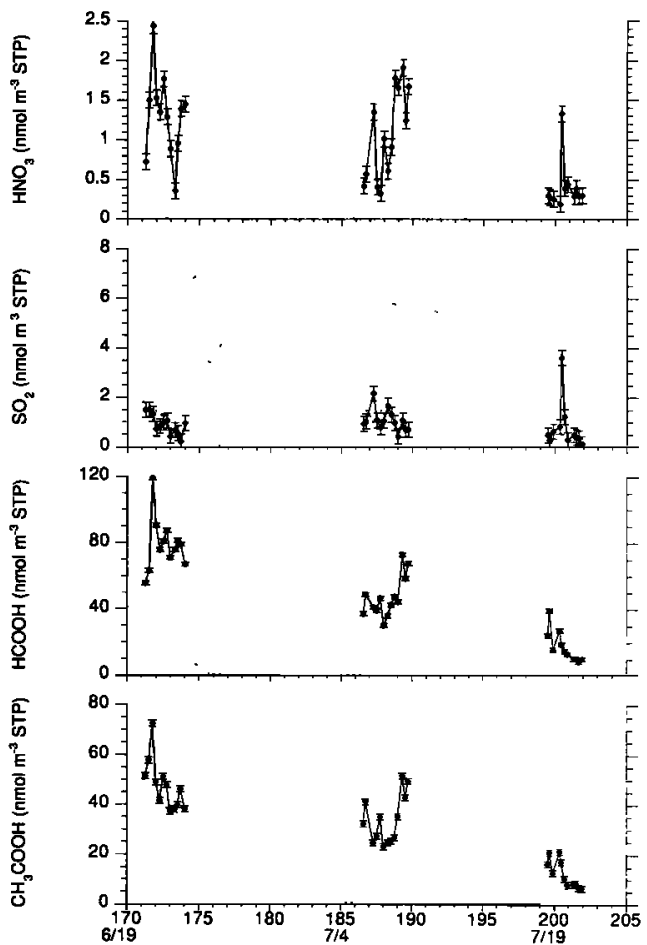

Figure 1. Concentrations of soluble acidic gases at Summit. For comparison, concentrations of aerosol-associated nitrate, sulfate, formate and acetate are shown in the dotted lines. phase over Summit (Fig. 1), in contrast to the high aerosolassociated concentrations at Barrow in winter (Table 1). $L i$ and Winchester [1989a] suggested that formate and acetate were partitioned predominantly into the condensed phase due to polar nighttime temperatures near $-25^{\circ} \mathrm{C}$. However, temperatures at Summit during sample collection ranged -5 to $-25^{\circ} \mathrm{C}$, suggesting that air temperature is not the sole control on the partitioning of these caboxylic acids in the atmosphere.

The concentrations of $\mathrm{HCOOH}$ and $\mathrm{CH}_{3} \mathrm{COOH}$ over the ice sheet at Summit were similar to those at Schefferville, Ontario, and more than twice those of "clean" free tropospheric air sampled during ABLE 3A and 3B (Table 1). These organic acids were well correlated at Summit $(r=0.93)$, with the ratio $\mathrm{HCOOH} / \mathrm{CH}_{3} \mathrm{COOH}$ in the range of 1.1-2.1 (mean 1.5 0.3 ).

Air-Snow Relationships. Contemporaneous sampling for gas, aerosol and snow phase chemistry was conducted during the late June and early July periods. Here we focus only on the first interval, but results were similar during July.

Beryllium-7 concentrations suggest that the air was relatively depleted of sub-micron aerosols at the beginning of the period (55-73 $\mathrm{fCi}^{7} \mathrm{Be} \mathrm{m}^{-3} \mathrm{STP}$ ) and became progressively cleaner during the first two days $\left(13 \mathrm{fCi}^{7} \mathrm{Be} \mathrm{m}^{-3}\right.$ STP). When the inversion broke down on the morning of 22 June, ${ }^{7} \mathrm{Be}$ concentrations increased by an order of magnitude (177 $\mathrm{fCi} \mathrm{m}^{-3} \mathrm{STP}$ ), suggesting replenishment of surface-level air by downward mixing [e.g., Dibb et al., 1992].

Nitrate concentrations in surface snow steadily increased from midday 20 June through midday 21 June as flurries added new snow to the initial layer (Fig. 2). The jump in concentration between 12:30 and 18:30 on 21 June is partly a sampling artifact; at $12: 30$ the initial $3-4 \mathrm{~cm}$-thick layer plus new snow that was still accumulating was sampled as the representative surface layer; later only the thin layer of new snow was included. The sharp increase in $\mathrm{NO}_{3}^{-}$ concentration between $00: 30$ and $6: 30$ on 22 June reflects $\mathrm{NO}_{3}^{-}$added by the deposition of rime ice during the fog event (1.3 nmol $\mathrm{g}^{-1}$ increase in $6 \mathrm{~h}$ ) (Fig. 2). 
Nitric acid was always the dominant fraction of total atmospheric nitrate during these three days. Concentrations rose sharply during the first $\mathbf{1 2}$ hours, then decreased during the snow flurries (Fig. 2). Concentrations of $\mathrm{HNO}_{3}$ dropped even lower during the fog event. After the inversion broke down, $\mathrm{HNO}_{3}$ concentrations increased; at the same time $\mathrm{p}-\mathrm{NO}_{3}^{-}$became detectable.

Aerosol $\mathrm{SO}_{4}-$ concentrations were quite low and comparable to those of $\mathrm{SO}_{2}$ early in the sampling period (Fig. 2). The period of snow flurries coincided with decreasing trends of ${\mathrm{p}-\mathrm{SO}_{4}}^{-}$and $\mathrm{SO}_{2}$, but had little influence on $\mathrm{SO}_{4}{ }^{-}$concentrations in surface snow. Deposition of rime ice increased $\mathrm{SO}_{4}{ }^{-}$concentrations in surface snow, perhaps at the expense of a slight decrease in $\mathrm{SO}_{2}$ concentrations (no aerosol samples for ionic species were collected overnight). After the fog dissipated, $\mathrm{p}_{-} \mathrm{SO}_{4}=$ concentrations increased with those of ${ }^{7} \mathrm{Be}$ and $\mathrm{p}-\mathrm{NO}_{3}$.

Concentrations of $\mathrm{HCOOH}$ and $\mathrm{CH}_{3} \mathrm{COOH}$ exceeded concentrations of $\mathrm{p}-\mathrm{HCOO}$ and $\mathrm{p}-\mathrm{CH}_{3} \mathrm{COO}^{-}$by nearly three orders of magnitude throughout the sampling period (Fig. 2). The snow flurries on 20-21 June coincided with decreasing trends of formate and acetate in both air and snow, in contrast to the opposing trends seen for nitrate in the two phases (Fig. 2). The fog event caused sharp increases in the concentration of carboxylates in the snow, but only slight depressions of gas phase concentrations. The small impact of fog on atmospheric concentrations of the carboxylic acids contrasts the decline in $\mathrm{HNO}_{3}$ during this event, but is in accord with the fact that their equilibrium solubilities are several orders of magnitude less than that of $\mathrm{HNO}_{3}[$ Klemm and Talbot, 1991]. Nearly all of the formate and acetate delivered to the snow by the rime event "disappeared" within 6 hours.

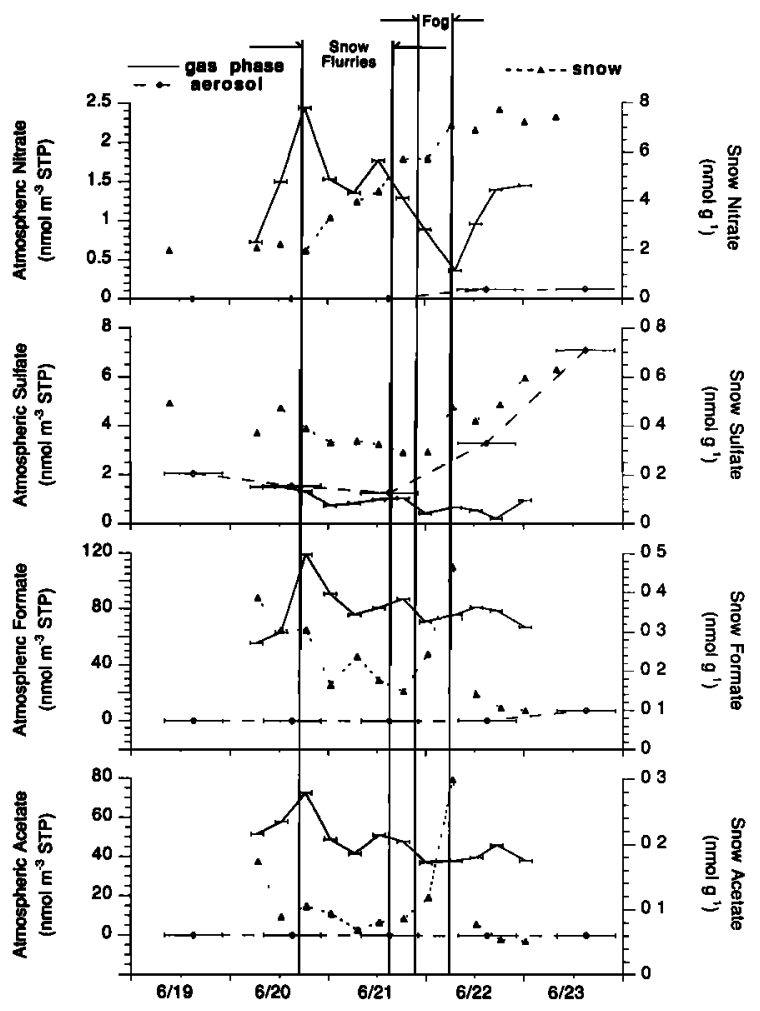

Figure 2. Relationships between the gas, aerosol and snow concentrations of nitrate, sulfate, formate and acetate during the $20-22$ June intensive sampling period.
It should be noted that $\mathrm{NO}_{3}^{-}$concentrations in snow were roughly an order of magnitude higher than those of $\mathrm{SO}_{4}{ }^{2}$ and the carboxylates (Fig. 2). In contrast, atmospheric concentrations of $\mathrm{HNO}_{3}$ were $\leq\left(\mathrm{SO}_{2}+\mathrm{p}-\mathrm{SO}_{4}{ }^{\circ}\right)$ and 20-50 times lower than those of $\mathrm{HCOOH}$ and $\mathrm{CH}_{3} \mathrm{COOH}$. In addition, the snow $\mathrm{NO}_{3}{ }^{-}$concentrations during this period (and throughout the summer) were considerably higher than those routinely reported for summer snow layers in snowpits and firn cores.

\section{Discussion}

The most intriguing findings of this study are the large enrichment of $\mathrm{NO}_{3}{ }^{-}$in snow relative to the atmospheric abundance of $\mathrm{HNO}_{3}$ and $\mathrm{p}-\mathrm{NO}_{3}{ }^{-}$, and the high gas phase concentrations of $\mathrm{HCOOH}$ and $\mathrm{CH}_{3} \mathrm{COOH}$. It is difficult to reconcile the observation of $\mathrm{p}^{-\mathrm{SO}_{4}}{ }^{=}$being three times more abundant than $\mathrm{HNO}_{3}$ plus $\mathrm{p}-\mathrm{NO}_{3}{ }^{-}$(Table 1) with $\mathrm{NO}_{3}{ }^{-} / \mathrm{SO}_{4}{ }^{-}$ in snow ranging 3-20. Part of this apparent discrepancy may be due to a sampling artifact. Dry deposition of $\mathrm{HNO}_{3}$ to the surface can create steep concentration gradients, making measurements at $1.5 \mathrm{~m}$ non-representative of the concentrations at slightly higher elevations [e.g., Lee et al., 1993]. However, Lee et al. [1993] report only a 2-fold increase in $\mathrm{HNO}_{3}$ from 2 to $30 \mathrm{~m}$ over basalt, suggesting that loss of $\mathrm{HNO}_{3}$ to the snow surface is not the only factor. It is possible that one, or more, of the $\mathrm{NO}_{\mathrm{y}}$ species not measured in this study is contributing to $\mathrm{NO}_{3}{ }^{-}$measured in surface snow.

Keene and Galloway [1988] suggested that the atmospheric lifetimes of $\mathrm{HCOOH}$ and $\mathrm{CH}_{3} \mathrm{COOH}$ are on the order of days, so it is surprising that their concentrations at Summit were similar to those at Schefferville and higher than mean concentrations in the Arctic summer free troposphere (Table 1). Lefer et al. [1994] have shown that biomass burning plumes in the northern high-latitude troposphere can contain elevated concentrations of both acids. Such plumes may reach Summit, but we would expect their influence to be episodic and not capable of maintaining such high concentrations for month-long periods (Fig. 1). Degassing of organic acids from surface snow (Fig. 2) might constitute a local source. However, this possible source appears too weak. For example, the 260 and $175 \mathrm{nmol} \mathrm{m}^{-2}$ of formate and acetate, respectively, apparently lost from the surface layer of snow on the morning of 22 June would only account for 7 and $5 \mathrm{nmol} \mathrm{m}^{-3}$ STP if they were well mixed through the boundary layer below the inversion observed at $50 \mathrm{~m}$ at 12:00. It may be that a deeper layer of surface snow is exchanging with near-surface air, but this explanation does not address the original source of carboxylates in Summit snow.

The partitioning of nitrate and the caboxylates just above the snow surface strongly favored the gas phase. The mean gas phase percentage of atmospheric formate and acetate was $>98 \%$ (Table 1). Similarly, the fraction of total atmospheric nitrate present as $\mathrm{HNO}_{3}$ at Summit (mean 93\%) was higher than most previous results (Table 1). This presumably reflects the acidic nature of the aerosol at Summit, but it is unclear how much displacement of $\mathrm{p}^{-\mathrm{NO}_{3}}{ }_{3}, \mathrm{p}-\mathrm{HCOO}-$ and $\mathrm{p}-\mathrm{CH}_{3} \mathrm{COO}^{-}$occurs in the atmosphere rather than on the filters as they become loaded with acidic $\mathrm{p}^{-\mathrm{SO}_{4}}{ }_{4}$.

On average, $75 \%$ of inorganic $S$ in the atmosphere at Summit was present as $\mathrm{p}^{-\mathrm{SO}_{4}}{ }_{4}$, a finding in accord with the seasonal decrease in $\mathrm{SO}_{2} / \mathrm{p}-\mathrm{SO}_{4}=$ in the Arctic Basin [Barrie and Bottenheim, 1991]. Concentrations of $\mathrm{SO}_{2}$ at Summit 
varied much less than those of $\mathrm{p}_{-} \mathrm{SO}_{4}=$ (Table 1 ; Figs. 1 and 2), resulting in wide variations in their ratio. This implies that $\mathrm{SO}_{2}$ is not efficiently removed from the air over Summit and that oxidation to $\mathrm{SO}_{4}{ }^{-}$is also suppressed (perhaps due to the very low humidity).

\section{Summary}

A pilot study in the harsh environment at Summit has demonstrated the feasibility of operating mist chamber samplers to provide data on the atmospheric concentrations of $\mathrm{HNO}_{3}, \mathrm{HCOOH}, \mathrm{CH}_{3} \mathrm{COOH}$ and $\mathrm{SO}_{2}$ directly over the Greenland ice sheet. Nitric and the carboxylic acids were well over an order of magnitude more abundant than their aerosol-associated anionic forms, while $\mathrm{SO}_{2}$ was only a small fraction of $\mathrm{SO}_{2}$ plus $\mathrm{p}^{-\mathrm{SO}_{4}}{ }_{4}$.

In snow, the relative abundance of these four acids was opposite their ranking in the atmosphere. Very low concentrations of the carboxylates in snow can be partially attributed to post-depositional loss processes operating on time scales of hours. We saw no convincing evidence of rapid $\mathrm{NO}_{3}{ }^{-}$loss from the snow during the summer season. However, observed concentrations in the surface layer much higher than those reported for summer layers buried in the snow pack (i.e., a year or more old) that $\mathrm{NO}_{3}{ }^{-}$losses must occur within the first 12 months after deposition. Additional sampling is needed to confirm and expand on these preliminary 1993 findings.

Acknowledgments. We thank M. Pender for assistance with sampling at Summit, and S. Whitlow, E. Scheuer and J.L. Jaffrezo for analysis of some of the samples. We are also grateful for the assistance of the GISP2 SMO, PICO and the 109th NYANG. We thank the Danish Research Commission for permission to study in Greenland. This work was partially supported by NSF grants DPP-9122555 to JED and DPP-9123082 to C. Davidson. This is contribution \# 94-01 of the Greenland Ice Sheet Project 2 (GISP2).

\section{References}

Barrie, L.A., and J.W. Bottenheim, Sulphur and nitrogen pollution in the Arctic atmosphere, in W. Sturges (ed.), Pollution of the Arctic Atmosphere, Elsevier Press, 1991.

Bottenheim, J.W., L.A. Barrie, and E. Atlas, The partitioning of nitrogen oxides in the lower Arctic troposphere during spring 1988, J. Atmos. Chem., 17, 15-27, 1993.

Dibb, J.E., J.-L. Jaffrezo, and M. Legrand, Initial findings of recent investigations of air-snow relationships in the Summit region of Greenland, J. Atmos. Chem., 14, 167-180, 1992.

Gorzelska, K., R.W. Talbot, K. Klemm, B.L. Lefer, O. Klemm, G.L. Gregory, B.A Anderson, and L.A. Barrie, Chemical composition of the atmospheric aerosol in the troposphere over the Hudson Bay lowlands and QuebecLabrador regions of Canada, J. Geophys. Res., 99, 17631780, 1994.

Keene, W.C., and J.N. Galloway, The biogeochemical cycling of formic and acetic acids through the troposphere: An overview of current understanding, Tellus, 4OB, 322-334, 1988.

Keene, W.C., et al., An intercomparison of measurement systems for vapor and particulate phase concentrations of formic and acetic acids, J. Geophys. Res., 94, 6457-6471, 1988.

Klemm, O., and R.W. Talbot, A sensitive method for measur ing atmospheric concentrations of sulfur dioxide, J. Atmos. Chem., 13, 325-342, 1991.

Klemm, O., R.W. Talbot, D.R. Fitzjarrald, K.I. Klemm, and B.L. Lefer, Low to middle tropospheric profiles and biosphere/troposphere fluxes of acidic gases in the summertime Canadian taiga, J. Geophys. Res., 99, 1687-1698, 1994.

Lee, G., L. Zhuang, B.J. Huebert, and T.P. Meyers, Concentration gradients and dry deposition of nitric acid vapor at the Mauna Loa Observatory, Hawaii, J. Geophys. Res., 98, 12,661-12,671, 1993.

Lefer, B.L., et al., Enhancement of acidic gases in biomass burning impacted air masses over Canada, J. Geophys. Res., 99, 1994.

Li, S.-M., and J.W. Winchester, Geochemistry of organic and inorganic ions of late winter Arctic aerosols, Atmos. Environ., 23, 2401-2415, 1989a.

Li, S.-M., and J.W. Winchester, Resolution of ionic compo nents of late winter Arctic aerosols, Atmos. Environ., 23, 2387-2399, 1989b.

Logan, J.A., Nitrogen oxides in the troposphere: Global and regional budgets, J. Geophys. Res., 88, 10,785-10,807, 1983.

Silvente, E., Contribution a l'etude de la fonction de transfert air neige en regions polaires; These de doctorat de l'Universite Joseph Fourier-Grenoble I, 1993.

Talbot, R.W., K.M. Beecher, R.C. Harriss, and W.R. Cofer, III, Atmospheric geochemistry of formic and acetic acids at a mid-latitude temperate site, J. Geophys. Res., 93, 1638-1652, 1988.

Talbot, R.W., A.S. Vijgen, and R.C. Harriss, Measuring tropospheric $\mathrm{HNO}_{3}{ }^{-}$: Problems and prospects for nylon filter and mist chamber techniques, J. Geophys. Res., 95, 7553-7561, 1990a.

Talbot, R.W., A.S. Vijgen and R.C. Harriss, Soluble species in the Arctic summer troposphere: Acidic gases, aerosols and precipitation, J. Geophys. Res., 97, 16,531-16,543, 1992.

Talbot, R.W., et al., Summertime distribution and relations of reactive odd-nitrogen species and $\mathrm{NO}_{y}$ in the troposphere over Canada, J. Geophys. Res., 99, 1863-1886, 1994.

Wolff, E.A., Nitrate in polar ice; paper presented at the NATO ARW on Ice Core Studies of Global Biogeochemical Cycles, 26-31 March, 1993 in Annecy, France, 1993.

M. H. Bergin, Department of Civil Engineering, Carnegie Mellon University, Pittsburgh, PA 15213. (e-mail: mb82 + @andrew.cmu.edu)

J. E. Dibb, Institute for the Study of Earth, Oceans and Space, University of New Hampshire, Durham, NH 03824. (email: jed@unh.edu)

R. W. Talbot, Institute for the Study of Earth, Oceans and Space, University of New Hampshire, Durham, NH 03824. (email: r_talbot@unhh.unh.edu)

(Received January 25, 1994; accepted February 25, 1994.) 